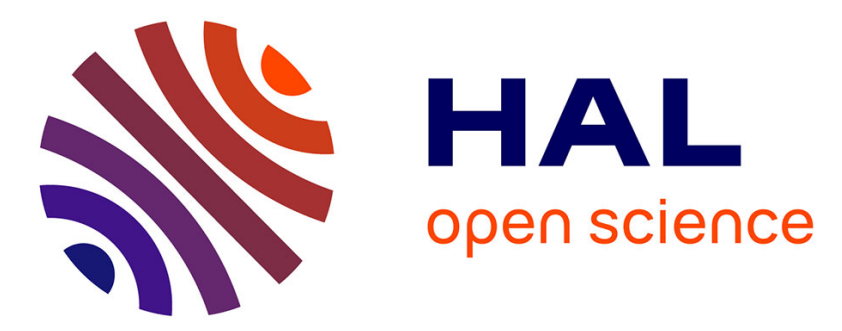

\title{
The variety, roasting, processing, and type of cultivation determine the low OTA levels of commercialized coffee in Chiapas State, Mexico
}

Maria Eugenia Aguilar-Alvarez, Gerardo Saucedo-Castañeda, Noel Durand, Isabelle Perraud-Gaime, Rosa Obdulia González-Robles, Gabriela Mariana Rodríguez-Serrano

\section{To cite this version:}

Maria Eugenia Aguilar-Alvarez, Gerardo Saucedo-Castañeda, Noel Durand, Isabelle Perraud-Gaime, Rosa Obdulia González-Robles, et al.. The variety, roasting, processing, and type of cultivation determine the low OTA levels of commercialized coffee in Chiapas State, Mexico. Food Control, 2021, 126, pp.108088. 10.1016/j.foodcont.2021.108088 . hal-03218805

\section{HAL Id: hal-03218805 https://hal.science/hal-03218805}

Submitted on 5 May 2021

HAL is a multi-disciplinary open access archive for the deposit and dissemination of scientific research documents, whether they are published or not. The documents may come from teaching and research institutions in France or abroad, or from public or private research centers.
L'archive ouverte pluridisciplinaire HAL, est destinée au dépôt et à la diffusion de documents scientifiques de niveau recherche, publiés ou non, émanant des établissements d'enseignement et de recherche français ou étrangers, des laboratoires publics ou privés. 


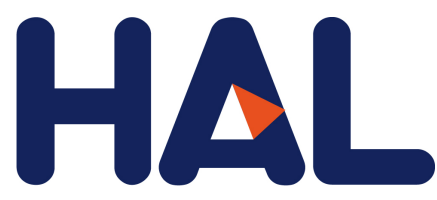

archives-ouvertes

\section{The variety, roasting, processing, and type of cultivation determine the low OTA levels of commercialized coffee in Chiapas State, Mexico}

Maria Eugenia Aguilar-Alvarez, Gerardo Saucedo-Castañeda, Noel Durand, Isabelle Perraud-Gaime, Rosa Obdulia González-Robles, Gabriela Mariana Rodríguez-Serrano

\section{To cite this version:}

Maria Eugenia Aguilar-Alvarez, Gerardo Saucedo-Castañeda, Noel Durand, Isabelle Perraud-Gaime, Rosa Obdulia González-Robles, et al.. The variety, roasting, processing, and type of cultivation determine the low OTA levels of commercialized coffee in Chiapas State, Mexico. Food Control, Elsevier, 2021, Food Control, 126, pp.108088. 10.1016/j.foodcont.2021.108088 . hal-03218805

\section{HAL Id: hal-03218805 \\ https://hal.archives-ouvertes.fr/hal-03218805}

Submitted on 5 May 2021

HAL is a multi-disciplinary open access archive for the deposit and dissemination of scientific research documents, whether they are published or not. The documents may come from teaching and research institutions in France or abroad, or from public or private research centers.
L'archive ouverte pluridisciplinaire HAL, est destinée au dépôt et à la diffusion de documents scientifiques de niveau recherche, publiés ou non, émanant des établissements d'enseignement et de recherche français ou étrangers, des laboratoires publics ou privés. 


\title{
Research Article
}

\section{The variety, roasting, processing, and type of cultivation determine the low OTA levels of commercialized coffee in Chiapas State, Mexico}

\author{
Maria Eugenia Aguilar-Alvarez ${ }^{\text {a }}$, Gerardo Saucedo-Castañeda ${ }^{\text {a }}$, Noel Durand ${ }^{\text {b,c }}$, \\ Isabelle Perraud-Gaime ${ }^{\mathrm{d}}$, Rosa Obdulia González-Robles ${ }^{\mathrm{e}}$, Gabriela Mariana Rodríguez- \\ Serrano ${ }^{\text {a, }}$ \\ ${ }^{a}$ Department of Biotechnology, Metropolitan Autonomous University, Iztapalapa Campus, ZC, 09340, Mexico City, Mexico \\ b CIRAD, UMR Qualisud, F-34398 Montpellier, France \\ ${ }^{\mathrm{c}}$ UMR Qualisud, Univ Montpellier, CIRAD, Montpellier SupAgro, Univ d'Avignon, Univ de La Réunion, Montpellier, France \\ ${ }^{\mathrm{d}}$ UMR-IMBE, Aix Marseille U, Avignon U., CNRS, IRD, Faculté de St Jérome, Case 421, F-F13397, Marseille Cedex 20, France \\ ${ }^{\mathrm{e}}$ Department of Mathematics, Metropolitan Autonomous University, Iztapalapa Campus, ZC, 09340, Mexico City, Mexico
}

A R T I C L E I N F O

\section{Keywords:}

Mexican coffee

Ochratoxin A

Wet-processed coffee

Arabica

Roasted

Chiapas

\begin{abstract}
A B S T R A C T
Ochratoxin A (OTA) in coffee is associated with serious health problems and significant economic loss. The state of Chiapas is the top coffee producer in Mexico, accounting for $41.3 \%$ of the national production, and the second largest organic coffee-producing area worldwide. Due to the lack of information about the OTA content in Chiapas coffee, 100 coffee samples from Chiapas were collected and classified according to their variety, type (roasted or nonroasted), processing and cultivation, in the $2017 / 2018$ cycle. The average OTA concentration in 97 of the analyzed samples was $0.41 \mu \mathrm{g} / \mathrm{kg}$. OTA was not detected in $52 \%$ of the samples; in $45 \%$ of the samples, the concentration ranged between 0.05 and $3.4 \mu \mathrm{g} / \mathrm{kg}$, below the limit of European regulations $(<5 \mu \mathrm{g} / \mathrm{kg})$, and in only $3 \%$ of the samples did the OTA values exceed the European regulations. The statistical analysis revealed that the prevalence of OTA depends on the variety, type, and processing ( $\mathrm{p} \leq 0.05$ ). No significant differences were observed between organic and conventionally cultivated coffee. In instant coffee (produced domestically), the average OTA concentration in 14 samples was $0.93 \mu \mathrm{g} / \mathrm{kg}$. The probability of finding OTA in instant coffee is higher than that in Chiapas coffee. These results suggest that the prevalence of OTA in coffee from Chiapas is low and that it is less likely to be found in wet-processed, roasted, arabica coffee.
\end{abstract}

\section{Introduction}

Ochratoxin A (OTA) is a secondary metabolite produced by filamentous fungi, mainly those of the Aspergillus and Penicillium genera. It can be found in various foods, such as cereals, nuts, spices and coffee. It has well-known nephrotoxic, immunosuppressive, teratogenic and carcinogenic activities, representing a serious health and food safety problem, in addition to causing significant economic losses (Codex Alimentarius, 2013; Heussner \& Bingle, 2015; IARC, 2002; JECFA, 2007). Few countries regulate the concentration of OTA in coffee (Duarte et al., 2010). European regulations have established the permitted levels of OTA at $<5 \mu \mathrm{g} / \mathrm{kg}$ and $<10.0 \mu \mathrm{g} / \mathrm{kg}$ in roasted and soluble or instant coffee, respectively (European-Commission, 2006).

Coffee is a widely consumed beverage, appreciated for its chemical and organoleptic qualities and its physiological effects, with high economic and social impact worldwide. In 2017, the foreign exchange generated by the exportation of coffee was 20 billion US dollars (International Coffee Organization (ICO), 2019). It is grown in more than 70 countries, including Mexico, which ranks eleventh in global production. In 2017, Mexico produced 859,992 tons of green coffee, most of it from Coffea arabica (95-97\%) (SADER-SIAP, 2019). The varieties of coffee that are cultivated conventionally in Mexico are arabica (arabica) and canephora (robusta). Only the former is cultivated organically; the robusta variety is dry-processed and mainly destined for the instant or soluble coffee industry (CEDRSSA, 2018).

In Mexico, the state of Chiapas is the main producer of conventional and organic coffee, contributing to $41.3 \%$ of national production (SADER-SIAP, 2019). The average annual temperature varies between

\footnotetext{
* Corresponding author.

E-mail addresses: meaa66@hotmail.com (M.E. Aguilar-Alvarez), saucedo@xanum.uam.mx (G. Saucedo-Castañeda), noel.durand@cirad.fr (N. Durand), gaimeisa@gmail.com (I. Perraud-Gaime), lulygo1749@gmail.com (R.O. González-Robles), gmrs@xanum.uam.mx (G.M. Rodríguez-Serrano).
} 
18 and $28{ }^{\circ} \mathrm{C}$, while the average annual rainfall ranges from 1200 to $4000 \mathrm{~mm}$, depending on the region, favoring the cultivation of coffee and other agricultural products (INEGI, 2017). To date, no studies have reported the prevalence of OTA in coffee grown and sold in Chiapas or Mexico.

It has been shown that OTA contamination in coffee depends on various factors, such as weather, geographical area (Benites et al., 2017), harvest management, wet or dry postharvest processing (Bucheli et al., 1998) and roasting (Castellanos-Onorio et al., 2011). Studies on OTA in coffee of African, Asian, South American and Latin American origin, particularly from Brazil, Colombia, Peru and Honduras, have shown that American coffee has a lower frequency of contamination and lower OTA concentrations (Benites et al., 2017; Romani et al., 2000).

Regarding processing and variety, it has been reported that the OTA concentration is higher in dry-processed coffee of the robusta nonroasted variety (dry cherries) (Khaneghah et al., 2019). In coffee from the Philippines, the proportion of samples with OTA in the robusta variety was $36.6 \%$, while in arabica, the proportion was lower (21.6\%), with an average OTA concentration of $120.2 \mu \mathrm{g} / \mathrm{kg}$ in dry-processed robusta cherries and $4.8 \mu \mathrm{g} / \mathrm{kg}$ in roasted robusta coffee. Moreover, in the arabica variety, the OTA concentration was $46.7 \mu \mathrm{g} / \mathrm{kg}$, and in roasted arabica coffee, the OTA levels were below $5 \mu \mathrm{g} / \mathrm{kg}$ (Barcelo \& Barcelo, 2018). In robusta coffee of the same origin, the average concentrations of OTA in ripe cherries (red coffee cherries) and in dry and green coffee were $32.86,56.77$, and $13.10 \mu \mathrm{g} / \mathrm{kg}$, respectively (Culliao $\&$ Barcelo, 2015), which indicates that under any condition, the OTA concentration in nonroasted robusta coffee exceeds that allowed by European regulations. Moreover, in Brazilian coffee, it has been reported that the OTA concentration in the arabica variety is higher in dry-processed coffee ( $>5 \mu \mathrm{g} / \mathrm{kg}$ ) than in wet-processed coffee (Batista et al., 2009).

The consumption of instant coffee is high due to the ease of preparation; however, this represents a risk due to the frequency of OTA contamination (Casal et al., 2014). Some OTA concentrations reported in instant coffee are 25.5 in South Korea (Lindenmeier et al., 2011), 7.25 in Chile (Galarce-Bustos et al., 2014), 1.99 in Argentina (Vanesa \& Ana, 2013), 6.40 in Italy (Vecchio et al., 2012) and $5.71 \mu \mathrm{g} / \mathrm{kg}$ in Malaysia (Lee et al., 2012).

This study aimed to quantify the concentration of OTA in coffee commercialized in Chiapas State, Mexico; relate the prevalence of OTA to the coffee variety (arabica or robusta), processing (wet or dry), type of cultivation (organic or conventional) and coffee type (roasted or nonroasted); and analyze the OTA content in nationally produced instant coffee.

\section{Materials and methods}

\subsection{Sample collection}

One hundred coffee samples of approximately $1 \mathrm{~kg}$ were collected during the 2017-2018 coffee growing cycle from markets in different areas of Chiapas State, Mexico (coordinates: $17^{\circ} 59^{\prime} 08^{\prime \prime} \mathrm{N}$ to $14^{\circ} 31^{\prime} 55^{\prime \prime} \mathrm{N}$ and $90^{\circ} 22^{\prime} 13^{\prime \prime} \mathrm{W}$ to $94^{\circ} 08^{\prime} 21^{\prime \prime} \mathrm{W}$ ) (Fig. 1). Samples were stored in sealed plastic bags for 2 weeks at room temperature $\left(20-25{ }^{\circ} \mathrm{C}\right)$ and relative humidity between 50 and $60 \%$ until OTA quantification. However, the producers fulfill the requirements of the Official Mexican Standard for coffee from Chiapas (NOM-169-SCFI-2007), which indicates moisture levels $<6 \%$ for roasted coffee and $10-12 \%$ for non-roasted coffee. Fourteen samples of different nationally distributed instant coffee brands were also collected from supermarkets. Chiapas has a limited

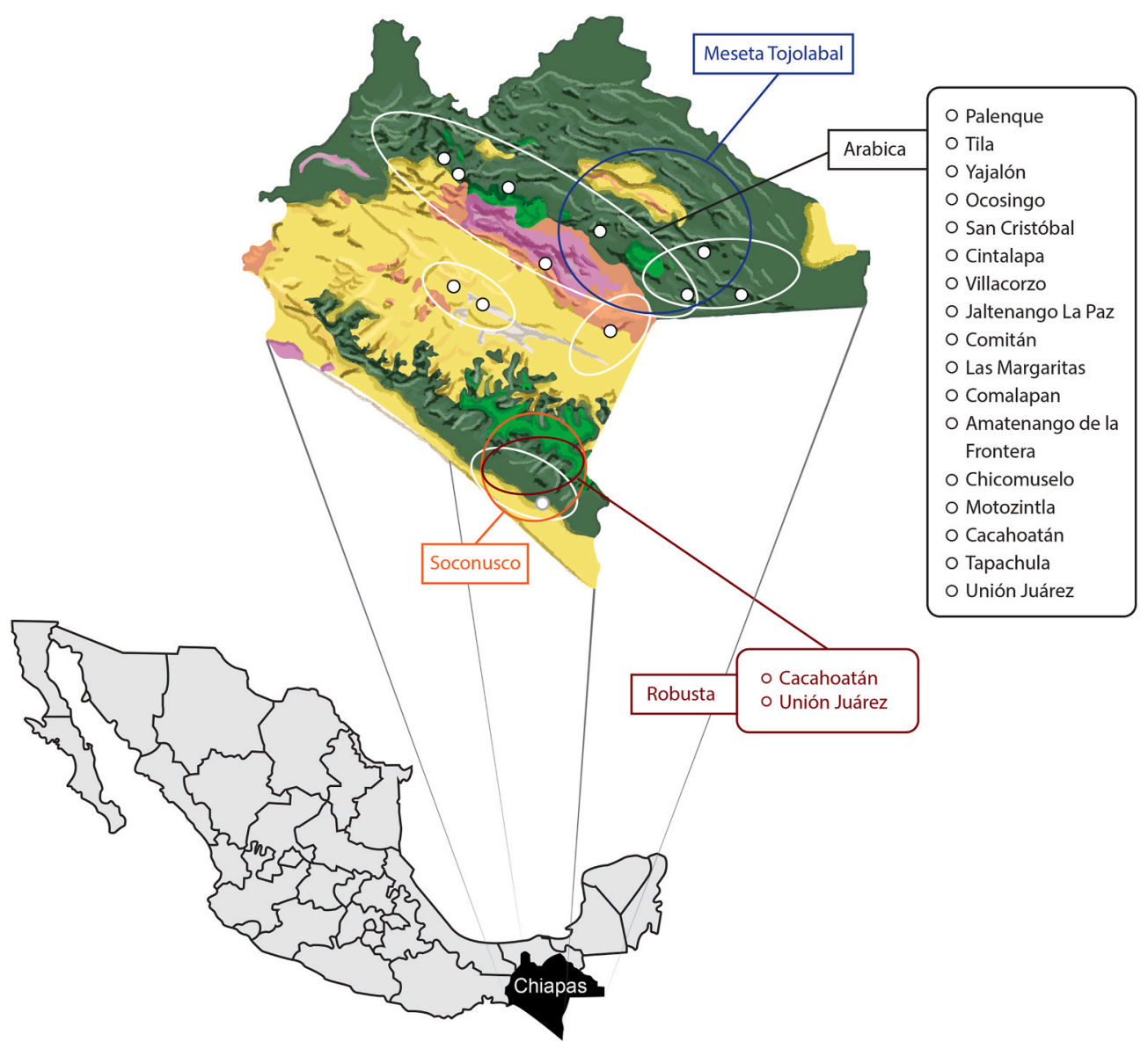

Fig. 1. Coffee sampling area in Chiapas State, Mexico. 
number of instant coffee-processing plants, and the composition of the coffee produced by these plants, in terms of variety and origin, is unknown. All (100\%) of the arabica or robusta coffee samples collected were wet (W)- or dry (D)-processed, respectively. All robusta coffee samples were cultivated conventionally.

\subsection{Sample classification}

The samples were classified according to variety (arabica (A) or robusta (R)), coffee type (roasted (R) or nonroasted (NR)), cultivation type (organic (O) or conventional (C)), and processing (wet $(\mathrm{W})$ or dry (D)). In addition, the samples were grouped as follows: ARC (arabica roasted conventional), ANRC (arabica nonroasted conventional), ARO (arabica roasted organic), ANRO (arabica nonroasted organic), RT (robusta roasted), RNT (robusta nonroasted), CHIAPAS (all coffee samples), INSTANT (instant coffee).

\subsection{Treatment of samples}

Each coffee sample was finely ground using a Moulinex ${ }^{\circledR}$ MC300132 $180 \mathrm{~W}$ coffee grinder to obtain particles smaller than $0.5 \mathrm{~mm}$.

\subsection{OTA extraction and quantification}

The OTA content of the coffee samples was analyzed according to the methodology reported by Durand (2012). Alkaline extraction was performed from $10 \mathrm{~g}$ of the ground coffee sample using methanol with the addition of $3 \%$ sodium bicarbonate (50:50). The sample was shaken at $150 \mathrm{rpm}$ for $30 \mathrm{~min}$ at $30^{\circ} \mathrm{C}$. The mixture was then centrifuged at 5000 rpm for $10 \mathrm{~min}$ at $5{ }^{\circ} \mathrm{C}$. A $10 \mathrm{~mL}$ aliquot of the supernatant was diluted with $30 \mathrm{~mL}$ of phosphate-buffered saline (PBS) at $\mathrm{pH}$ 7.3. This mixture was added to an immunoaffinity column (Puri-Fast ${ }^{\circledR}$ OTA HCS IAC, Fr) previously conditioned with $10 \mathrm{~mL}$ of PBS. The flow rate of the column was set at $2 \mathrm{~mL} / \mathrm{min}$. When all the sample had been added to the column, it was washed twice with PBS to eliminate impurities, and the OTA was subsequently eluted with $3 \mathrm{~mL}$ of HPLC grade methanol. The recovered fraction was completely evaporated under a nitrogen current at $70{ }^{\circ} \mathrm{C}$. The dry extract was reconstituted with $1 \mathrm{~mL}$ of a mixture of distilled water/methanol/glacial acetic acid (30:69:1 v/v/v). The flow rate used was $1 \mathrm{~mL} / \mathrm{min}$. OTA was quantified in an HPLC Shimadzu Prominence UFCL-XR (Shimadzu Corp., Japan) equipped with a fluorescence detector (Shimadzu RF-20A/XS) ${ }^{\text {with } \lambda} \mathrm{ab}=333 \mathrm{~nm}$ and $\lambda \mathrm{em}={ }^{460 \mathrm{~nm} \text {. HPLC was }}$ performed with a Hypersil ODS-2 (C-18, $250 \times 4.6 \mathrm{~mm}, 5 \mu \mathrm{m}$, Thermo Fisher Scientific $\left.{ }^{\circledR}\right)$ reversed-phase column and a precolumn with the same characteristics.

The injection volume was $50 \mu \mathrm{L}$. The ОTA retention time was 6.6-7.2 min. The ОTA standard curve was prepared from a standard OTA stock solution $(200 \mathrm{ng} / \mathrm{mL}$ : Sigma- Aldrich $_{\mathbb{R}}$ ); aliquots were diluted using a solution (methanol: water; 3:7: v:v) to reach nine levels of OTA concentration (ranging from 0.25 to $80 \mathrm{ng} / \mathrm{mL}$ ). Triplicate injections were performed on each sample. The calibration data fit a linear regression model with a high determination coefficient R2 equals 0.999 . The final OTA concentrations in coffee samples were expressed as $\mu \mathrm{g} / \mathrm{kg}$. The limit of detection (LOD) was 0.05 and the limit of quantification (LOQ) $0.15 \mu \mathrm{g} / \mathrm{kg}$. Both parameters were calculated based on the signal-tonoise ratio.

The OTA concentration was analyzed in coffee samples. A known amount of OTA was added to these samples. The total concentration of OTA was determined, and the recovery efficiency was estimated considering the following expression: Recovery rate $=$ ([OTA] experimental/[OTA] theoretical) * 100. The Relative Standard Deviation (RSD) and recovery rate of OTA were determined in triplicate showing an RSD of $4.8 \%$ and experimental recovery of $85.3 \%$.

OTA stability was determined in standard solutions and analyzed coffee samples. In both cases, they were stored at room temperature and refrigeration temperature $\left(4{ }^{\circ} \mathrm{C}\right)$ for two months. After this time, a difference of $2 \%$ was determined to the initial concentration. Therefore, OTA solutions were considered stable for two months. Duplicate analyses were prepared from those samples exhibiting a high level of OTA ( $>5 \mu \mathrm{g} / \mathrm{kg}$ ); pertinent dilutions were considered during the analysis.

\subsection{Statistical analysis}

The data were analyzed with descriptive statistics tools. Two ${ }^{\mathrm{x}}$ two contingency tables were used to estimate the proportion of samples in which OTA was present or absent. Fisher's exact and chi-squared $\left(\chi^{2}\right)$ tests were also used to confirm that the distribution of these proportions differed between the categories of each variable (variety, type, process, and cultivation). The Mann-Whitney $U$ test was used to contrast the medians of the concentrations in each category or group; NCSS $₫$ and SPSS ${ }^{\circledR}$ packages were used. Values with $\mathrm{p} \leq 0.05$ were considered statistically significant.

\section{Results}

\subsection{Analysis of OTA in Chiapas coffee}

The OTA content of the 100 Chiapas coffee samples grouped by variety, type and cultivation is shown in Fig. 2. OTA was not detected in 52 samples; 45 samples were positive for OTA, with concentrations between 0.05 and $3.4 \mu \mathrm{g} / \mathrm{kg}$; and in only 3 samples, the OTA concentration exceeded the permissible limits set by European regulations $(\leq 5 \mu \mathrm{g} / \mathrm{kg}$ ), with values of $10.28,12.50$ and $148.62 \mu \mathrm{g} / \mathrm{kg}$. The first of these three was from the ANRO group, and the latter two were from the ARC group. The average concentration in the 97 samples with and without OTA, which met the limits established by European regulations, was $0.41 \pm$ $0.62 \mu \mathrm{g} / \mathrm{kg}$. This result is relevant and shows that the coffee analyzed had the desirable characteristics for consumption and exportation. However, it should be noted that a high coefficient of variation and low frequency were found for samples with OTA levels higher than $5 \mu \mathrm{g} / \mathrm{kg}$, which is the limit set by European regulations. The data for instant coffee showed that $78.6 \%(n=11)$ of the samples had OTA concentrations within the limits set by European regulations $(\leq 10 \mu \mathrm{g} / \mathrm{kg})$; OTA was absent in only $21.4 \%(n=3)$ of the samples (Fig. 2).

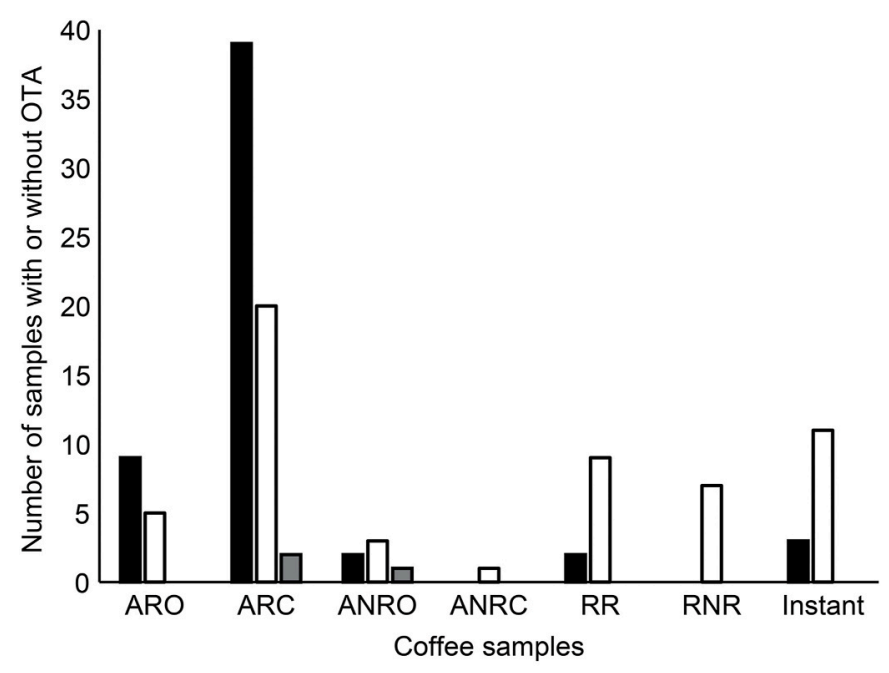

ND $\square 0.05 \leq 3.4(\mu \mathrm{g} / \mathrm{kg}$ OTA) $\square \geq 5(\mu \mathrm{g} / \mathrm{kg}$ OTA)

Fig. 2. Number of coffee samples with or without OTA grouped by their characteristics. ARO: arabica roasted organic; ARC: arabica roasted conventional; ANRO: arabica nonroasted organic; ANRC: arabica nonroasted conventional; RR: robusta roasted; RNR: robusta nonroasted, instant. 


\subsection{OTA in Chiapas coffee}

Analysis to compare the probabilities of the absence or presence of OTA in coffee according to variety (arabica or robusta), type (roasted or nonroasted), processing (wet or dry), and cultivation (organic or conventional) was obtained with the $\chi^{2}$ test by using the data for the 97 samples with OTA concentrations within the levels established by the European Union. Of these, 52 samples $(53.6 \%$ of the total) did not contain OTA, and the OTA concentration in the remaining samples fell within the limits of European regulations. The coffee samples without OTA were designated as being of excellent quality, and samples with OTA concentrations below European permissible limits OTA $(<5 \mu \mathrm{g} / \mathrm{kg})$ were of acceptable quality. Fig. 3 shows the percentages of samples with and without OTA, contrasting the two kinds of varieties, types, cultivation methods and processing methods through the $\chi^{2}$ test.

The proportions of coffee samples without OTA and with OTA $(<5$ $\mu \mathrm{g} / \mathrm{kg}$ ) showed significant differences $(\mathrm{p}<0.05$ ) between varieties, types, and processing methods but not between cultivation methods. OTA was absent in $11.1 \%$ of the robusta samples and $63.3 \%$ of the arabica samples. This shows that robusta coffee is more likely to contain OTA $(<5 \mu \mathrm{g} / \mathrm{kg})(88.9 \%)$ than arabica coffee (36.7\%) (Fig. 3A). In a comparison between roasted and nonroasted samples, the percentage of nonroasted coffee without OTA was $15.4 \%$, while the proportion for roasted samples was almost 4 times higher at 59.5\%; however, despite the higher likelihood of finding OTA in nonroasted coffee, the OTA content remained below the European limits (Fig. 3B).

Analysis of coffee samples by type of coffee bean processing (wet or dry; Fig. 3C) showed a similar trend as that observed in the comparison of varieties (Fig. 3A); this is explained by the fact that arabica coffee is wet-processed while robusta is dry-processed. A comparison of the prevalence of OTA between organically and conventionally cultivated coffee (Fig. 3D) showed no significant difference $(p>0.05)$. The estimated proportions of samples without OTA in both cultivation types differed by only five percentage units ( $57.9 \%$ for organic and $52.6 \%$ for conventional); consequently, similar proportions were seen in the data for samples with OTA ( $42.1 \%$ in organic and $47.4 \%$ in conventional).

A Mann-Whitney test was performed to compare the medians of OTA concentration from the different samples grouped according to variety, type, process and cultivation (Table 1). It was found that between coffee varieties, robusta had a median OTA of 0.74 with a variance interval between 0.05 and $1.0 \mu \mathrm{g} / \mathrm{kg}$, and these values were significantly higher

Table 1

Analysis of the medians of OTA concentration based on variety (arabica or robusta), coffee type (roasted or nonroasted), processing (wet or dry) and cultivation (organic or conventional) (Mann-Whitney $U$ test) ${ }^{\mathrm{a}}$.

\begin{tabular}{lcllll}
\hline Variable & Count & $\begin{array}{l}\text { Mean } \pm \text { SD } \\
(\mu \mathrm{g} / \mathrm{kg} \\
\text { OTA })\end{array}$ & $\begin{array}{l}\text { Median } \\
(\mu \mathrm{g} / \mathrm{kg} \\
\text { OTA })\end{array}$ & $\begin{array}{l}\text { 95\% LCL } \\
\text { of Median }\end{array}$ & $\begin{array}{l}\text { 95\% UCL } \\
\text { of Median }\end{array}$ \\
\hline Arabica/Wet & 79 & $\begin{array}{l}0.37 \pm \\
0.63\end{array}$ & 0 & 0 & 0 \\
Robusta/Dry & 18 & $\begin{array}{l}0.60 \pm \\
0.55\end{array}$ & 0.74 & 0.05 & 1.00 \\
Nonroasted & 13 & $\begin{array}{l}0.70 \pm \\
0.60\end{array}$ & 0.99 & 0.05 & 1.06 \\
Roasted & 84 & $\begin{array}{l}0.36 \pm \\
0.62\end{array}$ & 0 & 0 & 0.02 \\
Conventional & 78 & $\begin{array}{l}0.39 \pm \\
0.62\end{array}$ & 0 & 0 & 0.05 \\
Organic & 19 & $\begin{array}{l}0.48 \pm \\
0.65\end{array}$ & 0 & 0 & 0.92 \\
\hline
\end{tabular}

${ }^{a}$ Data did not have a normal distribution $(\mathrm{p} \leq 0.05)$. SD $=$ standard deviation. $\mathrm{LCL}=$ low control limit. $\mathrm{UCL}=$ upper control limit.

\section{A}

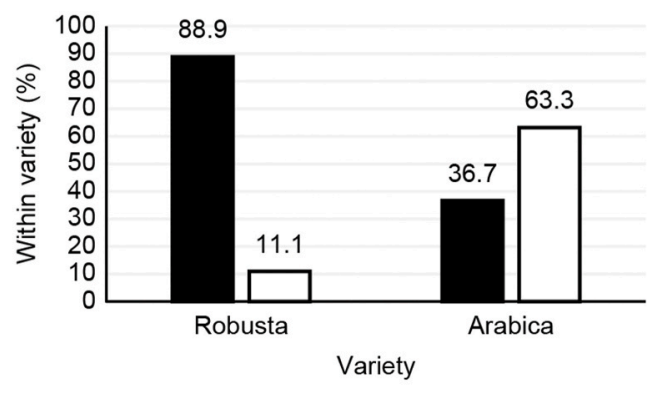

With OTA $(<5 \mu \mathrm{g} / \mathrm{kg}) \square$ Without OTA

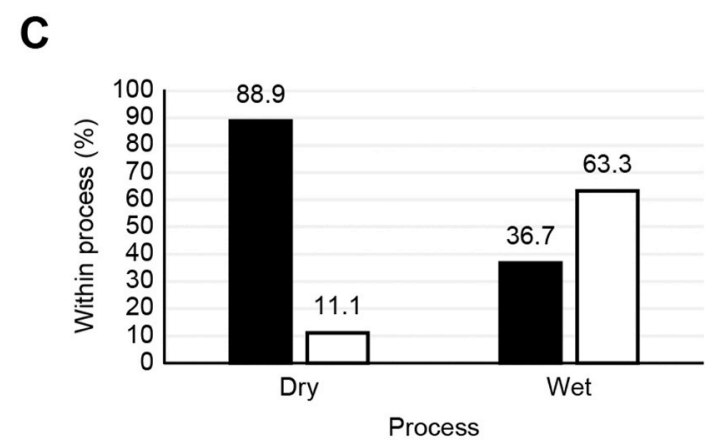

With OTA $(<5 \mu \mathrm{g} / \mathrm{kg})$
B

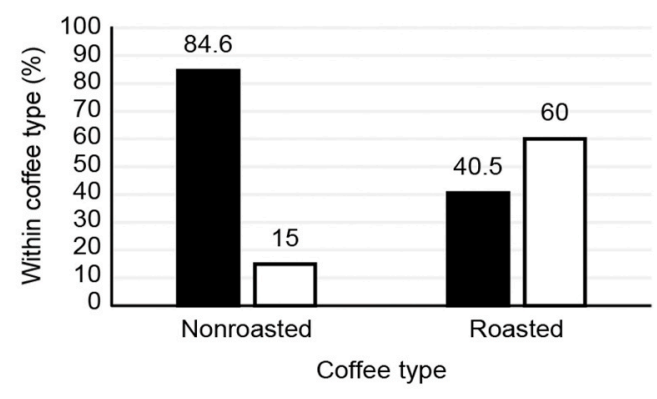

With OTA $(<5 \mu \mathrm{g} / \mathrm{kg}) \quad \square$ Without OTA

D

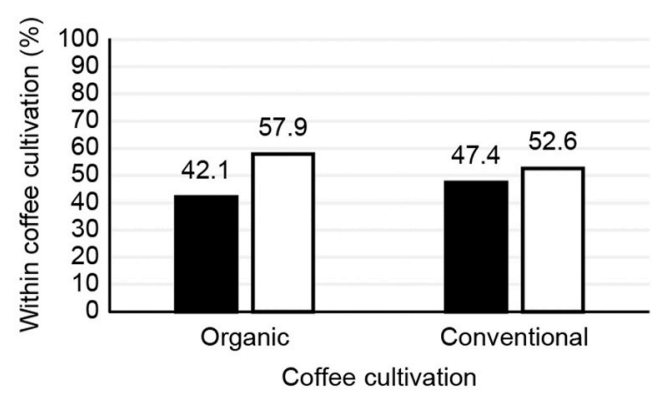

With OTA $(<5 \mu \mathrm{g} / \mathrm{kg}) \square$ Without OTA

Fig. 3. Percentage of coffee samples with or without OTA. Samples considered in these figures presented OTA concentrations below the European limit $(<5 \mu \mathrm{g} / \mathrm{kg})$. (A) Variety ( $\mathrm{p}<0.05)$. (B) Coffee type ( $\mathrm{p}<0.05)$. (C) Process $(\mathrm{p}<0.05)$. (D) Coffee cultivation type ( $\mathrm{p}>0.05)$. 
than those for arabica. The same behavior was found in the comparison between wet and dry processing, which was expected, given that all the robusta samples were dry-processed and the arabica samples were wetprocessed. Regarding coffee type, the median OTA concentration of roasted coffee was lower than that of nonroasted coffee, with a value of 0.98 and an interval between 0.05 and $1.06 \mu \mathrm{g} / \mathrm{kg}$. No significant differences were found in OTA concentration between conventional and organic cultivation ( $p>0.05$ ). It is worth noting that the robusta samples and nonroasted coffee presented higher median OTA concentration than the arabica samples, roasted coffee and both cultivation methods (Table 1).

\subsection{Comparison of OTA in instant coffee and Chiapas coffee}

When comparing the proportion of OTA-containing samples in the 97 samples from Chiapas, referred to as ground coffee, with that in the instant coffee samples, significant differences $(\mathrm{p}<0.05)$ were observed; the likelihood of finding samples without OTA was higher for ground coffee (53.6\%) than for instant coffee, in which estimated proportion of samples without OTA was $21.4 \%$.

The same behavior was observed when the percent distributions of the instant coffee samples with and without OTA were compared to those for the arabica variety and roasted coffee. The proportion of arabica samples without OTA was $63.3 \%$, and the proportion of roasted coffee samples without OTA was $59.5 \%$, while in instant coffee, this value dropped to $21.4 \%$. Furthermore, comparison of the data between robusta coffee and instant coffee and between nonroasted coffee and instant coffee showed no significant differences, and the likelihood of finding OTA was similar. In a comparison of the medians of the OTA concentration between instant coffee and ground coffee (Chiapas) (Table 2) and between arabica coffee and roasted coffee, the value for the instant coffee was higher at 0.99 with an interval of $0-1.37 \mu \mathrm{g} / \mathrm{kg}$ OTA ( $p<0.005)$. However, no significant differences were observed among the medians of instant coffee, robusta coffee and nonroasted coffee.

\section{Discussion}

The data collected showed the high quality of coffee traded locally inside the state of Chiapas, despite the lack of OTA regulation in Mexican coffee, in general, and in the Chiapas area in particular. The average OTA concentration in $97 \%$ of the analyzed samples was $0.41 \pm 0.62$, with values as high as 3.4 but always below $5 \mu \mathrm{g} / \mathrm{kg}$. Only $3 \%$ of samples presented concentrations higher than the limits established by European regulations $(<5 \mu \mathrm{g} / \mathrm{kg}$ OTA $)$.

In this study, the robusta variety and nonroasted coffee presented the highest percentages of samples contaminated with OTA $(89.9 \%$ and $84.6 \%$, respectively); in addition, the highest average OTA concentration was 0.60 for robusta coffee and $0.70 \mu \mathrm{g} / \mathrm{kg}$ for nonroasted coffee. These results show significant differences in the OTA content of arabica coffee beans, with an average of 0.37 , and in that of roasted coffee, with an average of $0.36 \mu \mathrm{g} / \mathrm{kg}$. Previous studies have shown that robusta coffee has a higher incidence of OTA (Benites et al., 2017) and that OTA

Table 2

Analysis of the median OTA concentration of ground coffee (Chiapas) and instant coffee (Mann-Whitney $U$ test) ${ }^{\mathrm{a}}$.

\begin{tabular}{ccllll}
\hline Variable & Count & $\begin{array}{l}\text { Mean } \pm \mathrm{SD} \\
(\mu \mathrm{g} / \mathrm{kg} \\
\text { OTA })\end{array}$ & $\begin{array}{l}\text { Median }(\mu \mathrm{g} / \\
\mathrm{kg} \text { OTA })\end{array}$ & $\begin{array}{l}\text { 95\% LCL of } \\
\text { Median }\end{array}$ & $\begin{array}{l}\text { 95\% UCL of } \\
\text { Median }\end{array}$ \\
\hline $\begin{array}{c}\text { Instant } \\
\text { coffee }\end{array}$ & 14 & $0.93 \pm 0.71$ & 0.99 & 0 & 1.37 \\
$\begin{array}{c}\text { Ground } \\
\text { coffee }\end{array}$ & 97 & $0.41 \pm 0.62$ & 0 & 0 & 0.05 \\
\hline
\end{tabular}

${ }^{a}$ Data did not have a normal distribution $(\mathrm{p} \leq 0.05) . \mathrm{SD}=$ standard deviation. $\mathrm{LCL}=$ low control limit. UCL $=$ upper control limit. tends to be present at higher concentrations in nonroasted coffee than in roasted, ground coffee since the amount of toxin can be reduced during the roasting process (Castellanos-Onorio et al., 2011; Suarez- Quiroz et al., 2005). In ground, roasted robusta coffee commercialized in Portugal, the reported OTA levels were between 0.79 and $1.56 \mu \mathrm{g} / \mathrm{kg}$, higher than those found in the analyzed Chiapas arabica coffee (trace amount, $0.86 \mu \mathrm{g} / \mathrm{kg}$ ). In coffee from India, the OTA contamination levels in samples of dry-cherry robusta coffee (nonroasted) were determined, and the maximum concentration found was $11.7 \mu \mathrm{g} / \mathrm{kg}$; in green organic coffee (nonroasted), the level was between 0.1 and $0.59 \mu \mathrm{g} / \mathrm{kg}$, while in roasted coffee, the mycotoxin was not detected (Gopinandhan et al., 2007). Similarly, in ground, roasted robusta samples from the Philippines, the OTA concentration found was $4.82 \pm 0.87 \mu \mathrm{g} / \mathrm{kg}$, while in green coffee (nonroasted) of the arabica and robusta varieties, the average OTA concentration was $46.65 \pm 16.33$ and $257 \pm 97.66 \mu \mathrm{g} / \mathrm{kg}$, respectively (Barcelo \& Barcelo, 2018), and these values exceeded the limits set by European regulations. The results show that the prevalence of OTA in coffee from Chiapas is low and are consistent with the values reported by Benites et al. (2017), who found that American coffee samples had significantly lower frequency of contamination and OTA levels-lower than those in coffee samples from African and Asian coffee-producing countries-as a consequence of climatic and processing conditions (Benites et al., 2017; Bucheli et al., 1998).

In this study, dry-processed coffee had the highest percentage of samples with OTA (89.9\%), containing an average of 0.60 and a median of $0.74 \mu \mathrm{g} / \mathrm{kg}$ OTA, values that were significantly different from those for wet-processed samples, which presented an average of $0.37 \mu \mathrm{g} / \mathrm{kg}$ OTA. Taniwaki et al. (2003) studied the presence of OTA in terms of the processing method, reporting that the OTA concentration in dry-processed samples was higher (up to $100 \mu \mathrm{g} / \mathrm{kg}$ ) than that in wet-processed samples.

Regarding the samples of organic coffee and conventional coffee, with and without OTA, our results (Fig. 3D) are consistent with those of Fabiana et al. (2014) and de Fátima Rezende et al. (2013), who found no significant differences between these cultivation systems in terms of the risk of OTA contamination caused mainly by ochratoxigenic filamentous fungi such as Aspergillus ochraceus. In other words, cultivation type is not a factor that determines the presence of OTA in coffee, but coffee variety, processing, and coffee type (roasted or nonroasted) are determining factors.

The instant coffee samples analyzed showed an average OTA content of $0.93 \mu \mathrm{g} / \mathrm{kg}$, higher than that in ground coffee $(0.41 \mu \mathrm{g} / \mathrm{kg}$ OTA), and $78.6 \%$ of the samples contained OTA, which is almost double the percentage for ground coffee. In the literature, OTA concentrations ranging from 0.1 to $25.50 \mu \mathrm{g} / \mathrm{kg}$ have been reported for instant coffee (Khaneghah et al., 2019).

In instant coffee samples commercialized in Chile, OTA was present in $100 \%$ of the samples, with an average concentration of 1.80 in a range of $0.28-5.58 \mu \mathrm{g} / \mathrm{kg}$ (Galarce-Bustos et al., 2014). In a study of 22 instant coffee samples in Argentina, OTA was present in $77.3 \%$ of the samples, with an average concentration of 1.99 in a range of $0.22-13.66 \mu \mathrm{g} / \mathrm{kg}$ (Vanesa \& Ana, 2013). In Italy, OTA was found in $95.5 \%$ of commercialized instant coffee samples, with an average concentration of 1.27 in a range of $0.32-6.40 \mu \mathrm{g} / \mathrm{kg}$. Notably, the average OTA concentration in Mexican instant coffee and its prevalence in the analyzed samples are lower than those reported in the aforementioned countries, and although OTA is present in Mexican coffee, the European limits are not exceeded. It has been reported that OTA levels increase in this type of coffee due to the concentration that occurs during the last stage of processing (Galarce-Bustos et al., 2014). It has also been pointed out that high levels of OTA in instant coffee may be a consequence of adulteration with coffee husk, especially of the cherry, a fraudulent practice that is sometimes used in the manufacture of instant coffee (Gopinandhan et al., 2007). In addition to the above, it is known that mixtures of dry-processed coffees, mainly robusta, with high OTA levels are used in the preparation of instant coffee (Culliao \& Barcelo, 2015; Duris et al., 
2010; Khaneghah et al., 2019), which can directly lead to high levels of this mycotoxin in instant coffee. The instant coffee samples analyzed in this work exhibited a low OTA concentration, which may indicate that the coffees used in the preparation of these instant coffees contained low OTA levels, as demonstrated in Chiapas coffee. The low prevalence of OTA may be the result of adequate manufacturing practices during coffee processing and the climatic and geographical conditions of the coffee cultivation areas.

These results confirmed that coffee from Chiapas exhibits, under the conditions of this study, a low OTA prevalence even when a large part of the coffee that is sold locally in markets is made on a small scale. Often, the coffee is not branded or registered with the health system and is not subjected to rigorous quality controls, such as those used to regulate exported coffee beans. Additionally, the quality of the coffee is directly dependent on the practices used by the producers during processing, storage and roasting, since the climatic and geographical characteristics of the different coffee growing areas sampled are favorable for the development of ochratoxigenic fungi (Batista et al., 2009; Benites et al., 2017; Khaneghah et al., 2019).

\section{Conclusion}

Mexico is an exporting country, and Chiapas State is the primary producer of organically and conventionally grown coffee. There have been no studies on the prevalence of OTA in cultivated and commercialized coffee in Chiapas. The evidence presented in this study showed that the great majority of the coffee beans analyzed (97\%) met European regulations. The coffee cultivation method (organic or conventional) is not a determining factor for the presence of OTA in coffee, but the variety, type and processing are determining factors; i.e., dry-processed roasted robusta coffee tends to present high OTA levels, but this level is significantly lower than that in nonroasted robusta coffee. In addition, instant coffee had higher levels of OTA than Chiapas coffee; however, these levels were below $10 \mu \mathrm{g} / \mathrm{kg}$ and therefore met the European standards for this type of coffee. It should be mentioned that even in the conditions of poverty and high marginalization prevalent in the coffeegrowing areas of Chiapas, good cultivation and processing practices may be closely related to the low levels of OTA in Chiapas coffee. The results obtained in this work indicated that Chiapas coffee presents low OTA levels, even lower than the limits established by European regulations, confirming that its consumption is suitable in terms of food safety and security, and this coffee presents desirable characteristics for consumption and exportation. This study may serve as a guide for consumers to choose coffee according to their preferences.

\section{Funding}

The authors would like to thank Consejo nacional de Ciencia y Tecnología (CONACYT) for its economic support through the Fondo de Cooperación INternacional en Ciencia y Tecnología (FONCICYT) Agence Nationale de la Recherche (ANR)-CONACYT (259874).

\section{Role of the funding source}

The sponsor(s) had not involvement in study design; in the collection, analysis, and interpretation of data; in the writing of the report; and in the decision to submit the article for publication.

\section{CRediT authorship contribution statement}

Maria Eugenia Aguilar-Alvarez: Conceptualization, Methodology, Data curation, Writing - original draft, Writing - review \& editing. Gerardo Saucedo-Castañeda: Visualization, Supervision. Noel Durand: Supervision. Isabelle Perraud-Gaime: Funding acquisition. Rosa Obdulia González-Robles: Methodology, Validation. Gabriela Mariana Rodríguez-Serrano: Conceptualization, Methodology,
Validation, Resources, Writing - review \& editing, Visualization, Supervision, Project administration, Funding acquisition.

\section{Declaration of competing interest}

None.

\section{Acknowledgements}

The authors would like to thank CONACYT for its economic support through the FONCICYT ANR-CONACYT (259874) project and the Secretaría de Educación Pública/Dirección General de Educación Tecnológica Agropecuaria y Ciencias del Mar for the doctoral grant awarded to Ma. Eugenia Aguilar Álvarez.

\section{References}

Alimentarius, C. (2013). Código de prácticas para prevenir y reducir la contaminación del cafe por ocratoxina A [Code of practice to prevent and reduce contamination of coffee by ochratoxin A.]. Codex Alimentarius, 72, 1-9.

Barcelo, J. M., \& Barcelo, R. C. (2018). Post-harvest practices linked with ochratoxin A contamination of coffee in three provinces of Cordillera administrative region, Philippines. Food Additives \& Contaminants Part A, Chemistry, Analysis, Control, Exposure \& Risk Assessment, 35(2), 328-340. https://doi.org/10.1080/ 19440049.2017.1393109

Batista, L. R., Chalfoun, S. M., Silva, C. F., Cirillo, M., Varga, E. A., \& Schwan, R. F. (2009). Ochratoxin A in coffee beans (Coffea arabica L.) processed by dry and wet methods. Food Control, 20(9), 784-790. https://doi.org/10.1016/j. foodcont.2008.10.003

Benites, A. J., Fernandes, M., Boleto, A. R., Azevedo, S., Silva, S., \& Leitão, A. L. (2017). Occurrence of ochratoxin A in roasted coffee samples commercialized in Portugal. Food Control, 73, 1223-1228. https://doi.org/10.1016/j.foodcont.2016.10.037

Bucheli, P., Meyer, I., Pittet, A., Vuataz, G., \& Viani, R. (1998). Industrial storage of green robusta coffee under tropical conditions and its impact on raw material quality and ochratoxin A content. Journal of Agricultural and Food Chemistry, 46(11), 4507-4511. https://doi.org/10.1021/jf980468

Casal, S., Vieira, T., Cruz, R., \& Cunha, S. C. (2014). Ochratoxin A in commercial soluble coffee and coffee substitutes. Food Research International, 61, 56-60. https://doi.org/ 10.1016/j.foodres.2014.04.045

Castellanos-Onorio, O., Gonzalez-Rios, O., Guyot, B., Fontana, T. A., Guiraud, J. P., Schorr-Galindo, S., Durand, N., \& Suárez-Quiroz, M. (2011). Effect of two different roasting techniques on the Ochratoxin A (OTA) reduction in coffee beans (Coffea arabica). Food Control, 22(8), 1184-1188. https://doi.org/10.1016/j. foodcont.2011.01.014

CEDRSSA (Centro de Estudios Para el Desarrollo Rural Sustentable y la Soberania Alimentaria). (2018). Reporte del café en méxico: Diagnóstico y perspectiva [report on coffee in Mexico: Diagnosis and perspective]. CEDRSSA.

Culliao, A. G., \& Barcelo, J. M. (2015). Fungal and mycotoxin contamination of coffee beans in Benguet province, Philippines. Food Additives \& Contaminants Part A, Chemistry, Analysis, Control, Exposure \& Risk Assessment, 32(2), 250-260. https://doi. org/10.1080/19440049.2014.1001796

Duarte, S. C., Lino, C. M., \& Pena, A. (2010). Mycotoxin food and feed regulation and the specific case of ochratoxin A: A review of the worldwide status. Food Additives \& Contaminants Part A, Chemistry, Analysis, Control, Exposure \& Risk Assessment, 27(10), 1440-1450. https://doi.org/10.1080/19440049.2010.497166

Durand, N. (2012-2021). Dynamique des populations microbiennes au cours du traitement post récolte du café et relations interspécifiques entre souches ochratoxinogènes. Université de Montpellier 2: Thèse de doctorat, biotechnologie, microbiologie. [Dynamics of microbial populations during post-harvest coffee processing and interspecific relationships between ochratoxinogenic strains]. University of Montpellier 2: PhD thesis. Biotechnology, Microbiology. Website visited on March 10 https://agritrop.cirad.fr/567930/1/do cument_567930.pdf.

Duris, D., Mburu, J. K., Durand, N., Clarke, R., Frank, J. M., \& Guyot, B. (2010). Ochratoxin A contamination of coffee batches from Kenya in relation to cultivation methods and post-harvest processing treatments. Food Additives \& Contaminants Part A, Chemistry, Analysis, Control, Exposure \& Risk Assessment, 27(6), 836-841. https:// doi.org/10.1080/19440040903571770

European-Commission. (2006). Reglamento CE N 1881/2006, por el que se fija el contenido máximo de determinados contaminantes en los productos alimenticios. Diario Oficial de la Unión Europea [Regulation CE N 1881/2006, which sets the maximum content of certain contaminants in food products. Official Journal of the European Union.

Fabiana, A., Sara, C., Mnica, C., Daiani, M., Cirillo, M., \& Batista, L. (2014). Diversity and association of filamentous fungi in coffee beans under organic and conventional cultivation. African Journal of Microbiology Research, 8(26), 2505-2512. https://doi. org/10.5897/AJMR2013.6571

de Fátima Rezende, E., Borges, J. G., Cirillo, M., Prado, G., Paiva, L. C., \& Batista, L. R. (2013). Ochratoxigenic fungi associated with green coffee beans (Coffea arabica L.) in conventional and organic cultivation in Brazil. Brazilian Journal of Microbiology, 44(2), 377-384. https://doi.org/10.1590/s1517-83822013000200006 
Galarce-Bustos, O., Alvarado, M., Vega, M., \& Aranda, M. (2014). Occurrence of ochratoxin A in roasted and instant coffees in Chilean market. Food Control, 46, 102-107. https://doi.org/10.1016/j.foodcont.2014.05.014

Gopinandhan, T., Velmourougane, K., Panneerselvam, P., Keshamma, E., \& Raghuramulu, Y. (2007). Occurrence of ochratoxin-A (OT-A) in green and commercial coffee samples. Journal of Food Science \& Technology, 44(3), 247-249.

Heussner, A. H., \& Bingle, L. E. (2015). Comparative ochratoxin toxicity: A review of the available data. Toxins, 7(10), 4253-4282. https://doi.org/10.3390/toxins7104253

SADER-SIAP (Secretaria de Agricultua y Desarrollo Rural - Servicio de Información Agroalimentaria y Pesquera [Secretary of Agriculture and Rural Development - AgriFood and Fisheries Information Service]. (2019). Panorama agroalimentario 2019. In S. de I Agroalimentaria y Pesquera (Ed.), Secretaria de agricultura y desarrollo social.

IARC (International Agency Research of Cancer). (2002). Some traditional herbal medicines, some mycotoxins, naphthalene and styrene. IARC monographs on the evaluation of carcinogenic risks to humans). IARC Press.

INEGI (Instituto Nacional de Estadística y Geografía). (2017). Anuario estadístico y geográfico de Chiapas 2017. Instituto Nacional de Estadística y Geografía [Chiapas Statistical and Geographic Yearbook 2017. National Institute of Statistics and Geography].

International Coffee Organization. (2019). Coffee development report 2019. Federal Mi; Deutsche Gesellschaft für Internationale Zusammenarbeit (GIZ).

JECFA (Joint FAO/WHO Fxpert Committee on Food Additives). (2007). WHO technical report series 947 evaluation of certain food additives and contaminants sixty-eighth report of the joint FAO/WHO expert committee on food additives food and agriculture organization of the United Nations world health organization (FAO/WHO).

Khaneghah, A. M., Fakhri, Y., Abdi, L., Coppa, C. F. S. C., Franco, L. T., \& de Oliveira, C. A. F. (2019). The concentration and prevalence of ochratoxin A in coffee and coffee-based products: A global systematic review, meta-analysis and metaregression. Fungal Biology, 123(8), 611-617. https://doi.org/10.1016/j. funbio.2019.05.012
Lee, T. P., Saad, B., Khayoon, W. S., \& Salleh, B. (2012). Molecularly imprinted polymer as sorbent in micro-solid phase extraction of ochratoxin A in coffee, grape juice and urine. Talanta, 88, 129-135. https://doi.org/10.1016/j.talanta.2011.10.021

Lindenmeier, M., Schieberle, P., \& Rychlik, M. (2011). Determination of ochratoxin A in food: Comparison of a stable isotope dilution assay, liquid chromatographyfluorescence detection and an enzyme-linked immunosorbent assay. Mycotoxin Research, 27(2), 115-121. https://doi.org/10.1007/s12550-010-0084-1

Norma Oficial Mexicana NOM-169-SCFI-2007. Café Chiapas-Especificaciones y métodos de prueba.Diario Oficial de la Federación. [Official Mexican standard NOM-169SCFI-2007, Chiapas' Coffee Chiapas-Specifications and test methods of the Official Gazette of the Federation]. Web site visited on March 4, 2021 http://diariooficial. gob.mx/nota detalle.php?codigo $=4966402 \&$ fecha $=26 / 03 / 2007$.

Romani, S., Sacchetti, G., Chaves López, C., Pinnavaia, G. G., \& Dalla Rosa, M. (2000). Screening on the occurrence of ochratoxin A in green coffee beans of different origins and types. Journal of Agricultural and Food Chemistry, 48(8), 3616-3619. https://doi.org/10.1021/jf990783b

Suarez- Quiroz, M., Louise, B., Gonzalez-Rios, O., Barel, M., Guyot, B., Schorr-Galindo, S., \& Guiraud, J. P. (2005). The impact of roasting on the ochratoxin A content of coffee. International Journal of Food Science and Technology, 40(6), 605-611. https://doi.org/ 10.1111/j.1365-2621.2005.00958.x

Taniwaki, M. H., Pitt, J. I., Teixeira, A. A., \& Iamanaka, B. T. (2003). The source of ochratoxin A in Brazilian coffee and its formation in relation to processing methods. International Journal of Food Microbiology, 82(2), 173-179. https://doi.org/10.1016/ S0168-1605(02)00310-0

Vanesa, D., \& Ana, P. (2013). Occurrence of ochratoxin A in coffee beans, ground roasted coffee and soluble coffee and method validation. Food Control, 30(2), 675-678. https://doi.org/10.1016/j.foodcont.2012.09.004

Vecchio, A., Mineo, V., \& Planeta, D. (2012). Ochratoxin A in instant coffee in Italy. Food Control, 28(2), 220-223. https://doi.org/10.1016/j.foodcont.2012.04.029 